\title{
乳癌検診における超音波検査の意義 (4)
}

\section{超音波検査のみによる大阪市乳癌検診}

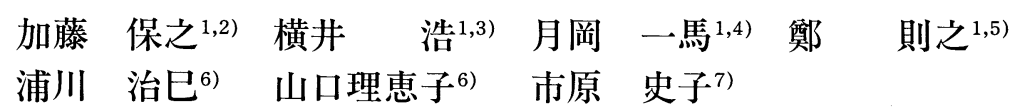

大阪市乳がん超音波判定委員会1)

大阪市立大学医学部第 1 外科 ${ }^{2)}$, 日生病院 ${ }^{3)}$

大阪総合医療センター救急救命センター4)

大阪府医師会5), 大阪市環境保健局 ${ }^{6)}$

大阪市保健衛生検査所 ${ }^{7)}$

Key words：乳癌検診，超音波，大阪市

\section{はじめに}

乳癌検診の方法は各地域の諸事情によりさまざ まである。多くは老健法で示された視触診法を基 本に行われている。しかしながら，この方法には 問題も少なくないことより，何らかの画像診断を 加えて行おうとの機運がある。画像診断としてマ ンモグラフィ，あるいは超音波診断が候補として あげられる。大阪市では1988年11月から，超音波 診断装置を積載した検診車による出張方式で乳癌 検診を行っており ${ }^{1 \sim 6)}$ ，その検診方法，成績と問題 点について述べる。

\section{1. 方 法}

検診方法は各市町村で一般に行われている方法 とは異なり，視触診は行っていない。これを補う ために，超音波検査にさきだって保健婦による自 己検診の指導，問診を徽底している。問診では， とくに腫瘤自覚の有無, 乳頭の変形, 異常分泌, 乳癌の家族歴などを聞いている。超音波診断装置 MAT-1 (旭メディカル社製) は大型の水槽をもって

別冊請求先：干545 大阪市阿倍野区旭町 $1-5-7$ 大阪市立大学医学部第 1 外科 加藤保之
おり，被検者は腹臥位で乳房を懸垂させた姿勢で 超音波検査技師が撮像する。診断装置の下方より $5.5 \mathrm{MHz} ， 4$ 個の探触子で, 懸垂した乳房に対して $15 \mathrm{~cm}$ 幅を $3 \mathrm{~mm}$ 間隔でコンパウンド走査し, 光 ディスクに超音波断層像を記録しており，1例に ついて両側乳房102枚の超音波画像をえる。これら の画像を 1 例に対して，2名の大阪市乳がん超音 波判定委員が，超音波画像を判定委員それぞれが 読影しやすい早さで, CRT ディスプレイ上に呼び 出す, いわゆる rapid viewing 法7)で読影し, 腫瘤 の位置, 所見の impressionを記載し, 問診も参考 にして総合判定している。総合判定は異常を認め ず, 要観察, 要精査の 3 段階としている(図 1)。判 定のガイドラインは超音波画像から腫瘤像, 乳管 拡張像, 囊胞像を, 個人票の問診から乳癌の家族 歴, 自覚症状, 乳頭異常分泌をそれぞれ参考とし ている(表 1)。乳がん検診結果通知書は図 2のよう な説明を添え, 結果を報告している。超音波の総 合判定用紙(図 1) とは複写式になっており, 判定を 記入すれば $1,2 ， 3$ の番号の上に写るようになっ ており，転記ミスがないように工夫されている。

\section{2. 成 績}

1988年11月から1993年 3 月までに, 受診者 69,069 


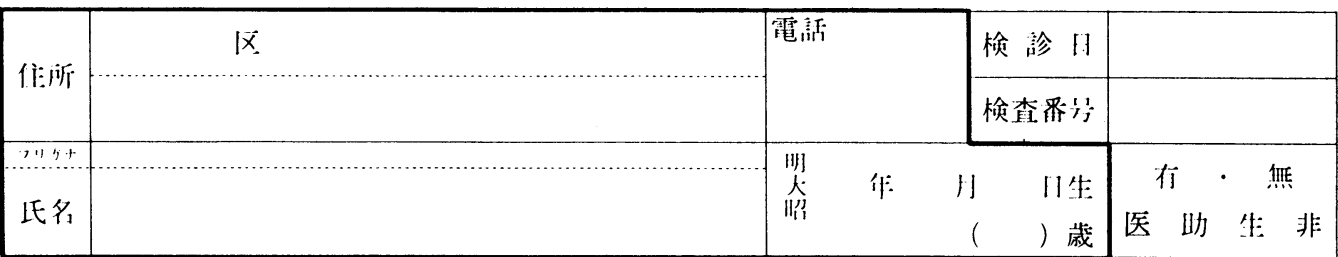

次の質問にO印または記入してください。

質 丳 者

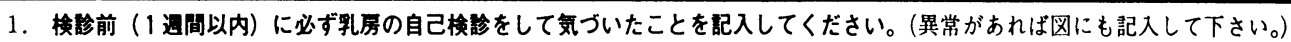

(1) $l=\eta$

(2) 痛 み

(3) 乳首及び乳房皮ふの

くぼみ・変形

(4) 乳首からの異常分泌

無・有 (右・左, いつから

生理と関係が ある・ない

無・有 (右・左, いつから

生理と関係がある・ない

無・有（右・左，いつから

無・有 (右・左, いつから 血性・白い. 透明
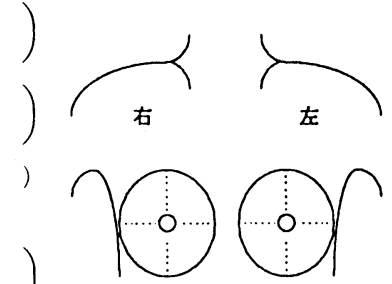

右・左)

2. 今までに乳腺の病気をしたことは 無・有（裁比）（病名

（手術した・しない）※手術した部位を上の戌に記入してください

3. 血のつながった人のうち乳がんにかかった人は

無·有（祖母·好・姉·妹・娘・その他）・わからない

4. 今までに乳がん検診を受けたことは

無・有〔いつ年 月・どこで( 結果 買堂なし・異常あり(

5. 乳房の自己検診

毎月している・時々している・していない

（追加記載事項）胸部の皮ふ疾患：

無 · 有

6.0 出産子供（）人. 閉経（）墄

○柆 乳 現在授乳している・していない

この欄は記入しないでください

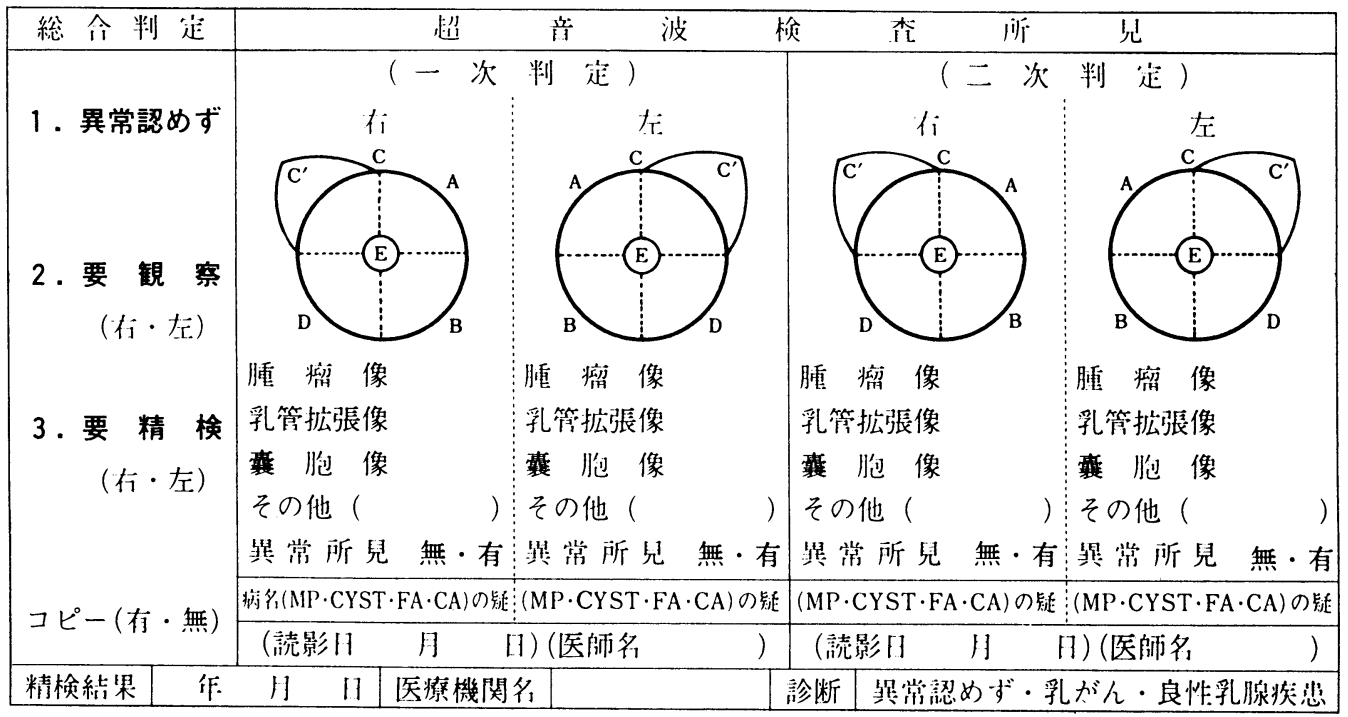

図 1. 大阪市乳がん検診個人票 
住沂

IEY

棣

\title{
乳がん検診結果通知書
}

\section{保健所長}

\author{
先日受診された乳がん検診（超音波断層撮影）の結果は、次のとおり \\ でしたのでお知らせします。（○印があなたの結果です。）
}

結果

\section{1．異常は認められません。}

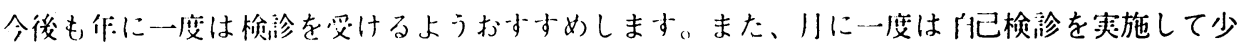
しでも暴常に気づいたら、医療機関で晾察を受けてください。

\section{2. 経過钼察が必要です。}

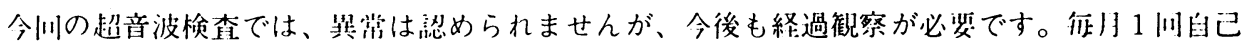
検診をして变化があれば、医潦機関で竝察を受けてください。

\section{3 さらに詳しい検査を受ける必要があります。}

必ずしも病気があるということではありません。あまり心配なさらずに、精密㭘査を受けられ るようおすすめします。

精密検査を受けるうj法について机谈しますので、この通知苦をご持参のうえ、

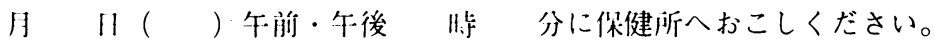

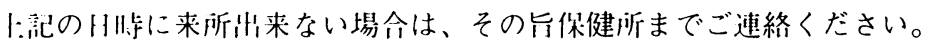

図 2. 乳がん検診結果通知書 
表 1. 判定のガイドライン

(平成5.7.8改正)

画像からみた判定

\begin{tabular}{c|c|c|c|c}
\hline \multicolumn{2}{c|}{} & 異常認めず & 要観察 & 要精検 \\
\hline \multirow{2}{*}{ 腫瘤像 } & CA または疑い & & & $\bigcirc$ \\
\cline { 2 - 5 } & $\mathrm{FA}$ & & & $\bigcirc$ \\
\hline \multirow{2}{*}{ 乳管拡張像 } & 軽度 & & & \\
\hline & 著明 & & & $\bigcirc$ \\
\hline 囊胞像 & & & & $\bigcirc$ \\
\hline
\end{tabular}

個人票からの判定(画像異常なし)

\begin{tabular}{|c|c|c|c|}
\hline & & 要観察 & 要精検 \\
\hline 乳がんの家族歴 & 祖母, 母, 叔母, 姉妹, 娘 & $\bigcirc$ & \\
\hline \multirow{2}{*}{ 自覚症状 } & しこり & 0 & \\
\hline & 乳頭変形(条件付) & 0 & \\
\hline \multirow{3}{*}{ 乳頭異常分泌 } & 血性 (赤・黒・茶色) & & 0 \\
\hline & 透明 (透明な黄色) & & $\bigcirc$ \\
\hline & 白色(混濁した黄色) & 0 & \\
\hline
\end{tabular}

表 2. 大阪市乳がん検診実施状況

\begin{tabular}{|c|c|c|c|c|}
\hline 年＼cjkstart度 & 受診者 & 要精検者 & 精検受診者 & 発見乳がん \\
\hline $1988.11 \sim$ & 4,182 & $470(11.2)$ & $453(96.4)$ & $5(0.12)$ \\
\hline 1989. & 15,039 & $1,396(9.3)$ & $1,353(96.9)$ & $7(0.07)$ \\
\hline 1990. & 15,933 & $1,875(11.8)$ & $1,802(96.1)$ & $11(0.07)$ \\
\hline 1991. & 17,305 & $2,124(12.3)$ & $2,080(97.9)$ & $14(0.08)$ \\
\hline 1992. & 16,610 & $1,683(10.1)$ & $1,527(90.7)^{*}$ & $20(0.12)$ \\
\hline 計 & 69,069 & $7,548(10.9)$ & $7,215(95.6)$ & $57(0.08)$ \\
\hline
\end{tabular}

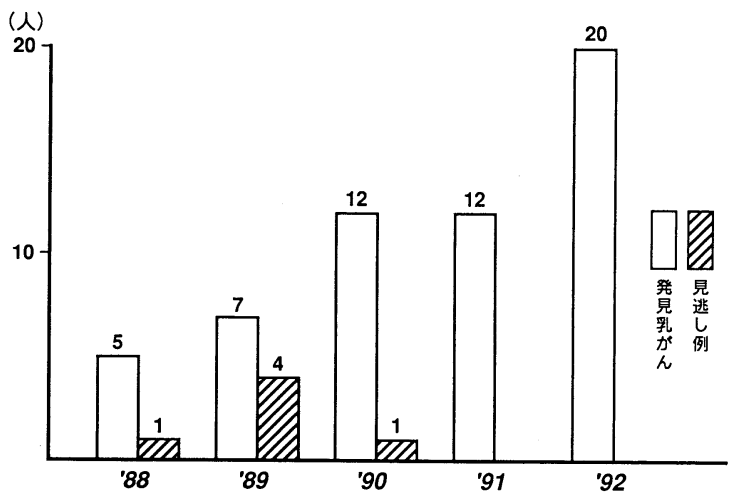

図 3. 発見乳がん数と見逃し例数の年度別推移
名に超音波検診を施行し, 要精検率は $10.9 \%$, 精 検受診率は $95.6 \%$, 発見乳癌は 57 例で癌発見率は $0.08 \%$ であった(表 2)。

図 3 に年度別の発見乳癌数と見逃し例の推移を 示す。発見乳癌数は漸次増加しており，1988年11 月から 2 年間に 6 例の見逃し例があったが，最近 の 3 年間には見られていない。見逃し例のうち 4 例は腫瘤径が $2 \mathrm{~cm}$ 以下であった。

見逃し例の超音波像を図 4 に示す。55歳の女性。 上段は右，下段は左乳房の超音波断層像で，乳房 


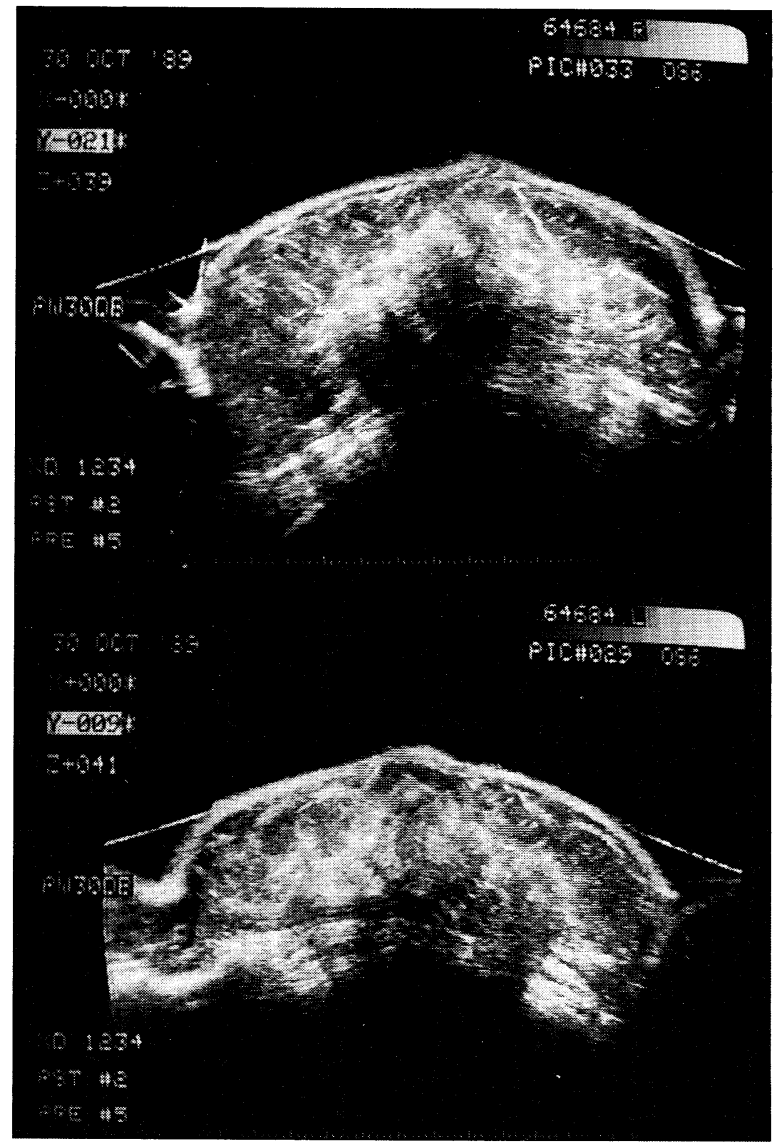

図 4. 55歳，女性. 見逃し例の超音波像.

の中央，深部に不整な低エコー域がみられるが， 用いている超音波診断装置ではしばしば正常でも 類似した像がみられ，左右ともにみられたことよ り異常なしとしたが, $3 \mathrm{~cm}$ を超す両側の進行乳癌 であった。問診では腫瘤の自覚はなかった。

図 5 は正常乳房の超音波断層像である。上段は 右，下段は左乳房で乳頭下に不整な腫瘤様の低工 コ一像がみられる。また，乳房の下方の外側にも 腫瘤様の低エコー像がしばしば見られる(図 6)。こ れらのアーチファクトはこの診断装置がコンパウ ンド走查により超音波断層像を作っていることに 起因しており，超音波判定をときに困難なものと している。

医療機関から精検結果の報告があった乳癌 48 例 についてみると, 年㱓は36歳から73歳, 50歳代が

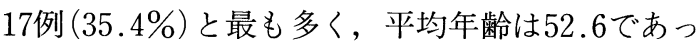
た。Tnm 分類は T1が18例, T2が20例で n0が28例, 1 例に遠隔転移がみられた。16例 (33.3\%) は腫瘤

図 6. 正常乳房の超音波像. 乳房の下方の外側にも腫瘤 様の低エコー像がしばしば見られる。
6 . 19048

63559.

x-

R-grax.

$2+919$

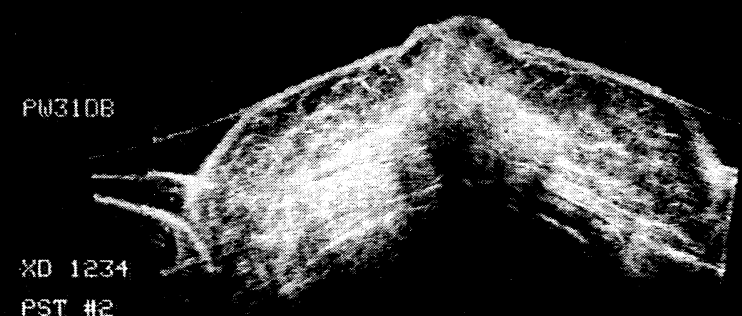

PST \#Z

PRE \#5

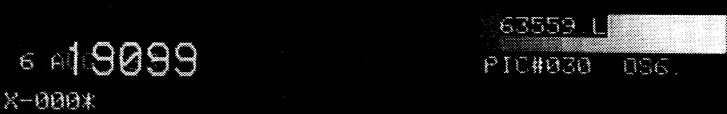

Y-gाa*

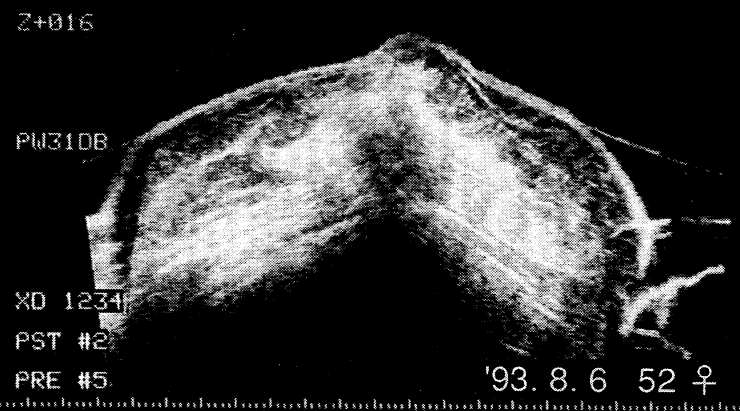

図 5. 正常乳房の超音波像. 乳房の中央, 深部に不整な 低エコー域がみられる。

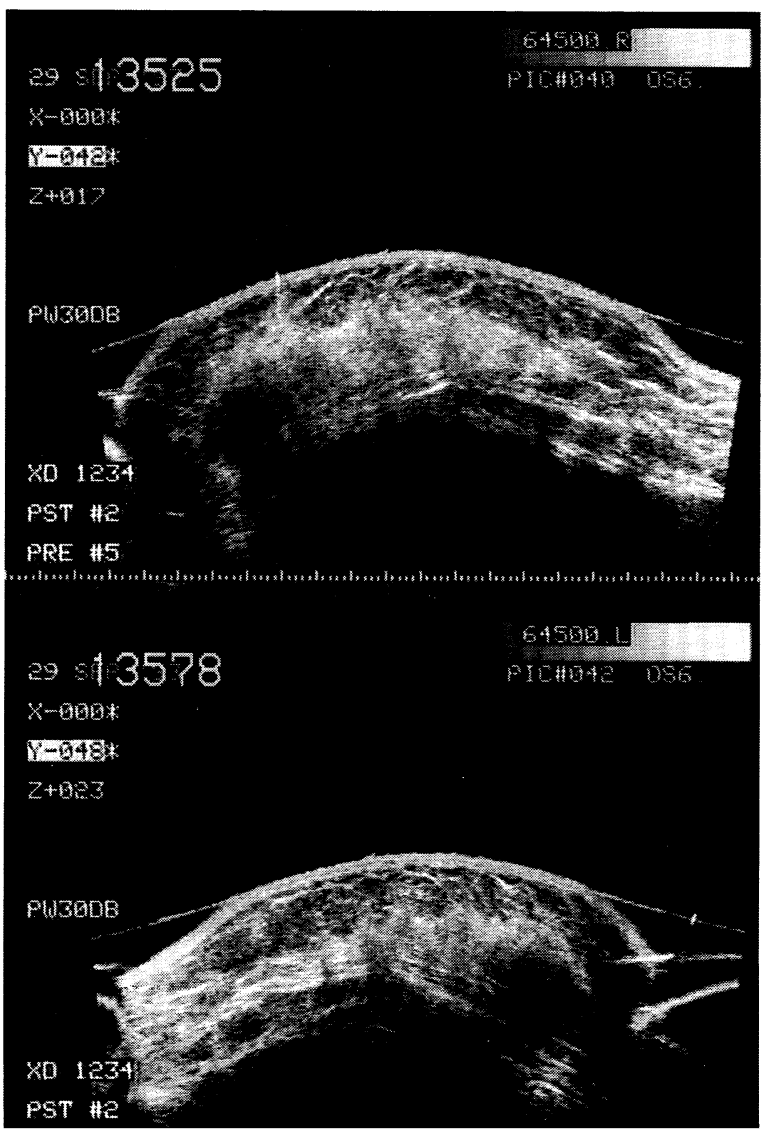


表 3. 精検結果報告のあった乳癌48例の $\mathrm{Tnm}$ 分類 $\mathrm{T}$

\begin{tabular}{lr}
\hline T0, Tis & $3(6.3)$ \\
T1 & $18(37.5)$ \\
T2 & $20(41.6)$ \\
T3 & $5(10.4)$ \\
T4 & $2(4.2)$ \\
\hline
\end{tabular}

48

\begin{tabular}{lr}
\multicolumn{2}{c}{$\mathrm{n}$} \\
\hline $\mathrm{n} 0$ & $28(58.2)$ \\
$\mathrm{n} 1 \alpha$ & $8(16.7)$ \\
$\mathrm{n} 1 \beta$ & $2(4.2)$ \\
$\mathrm{n} 2$ & $2(4.2)$ \\
不明 & $8(16.7)$ \\
\hline
\end{tabular}

48

$\mathrm{m}$

\begin{tabular}{lr}
\hline $\mathrm{m} 0$ & $47(97.9)$ \\
$\mathrm{m}$ & $1(2.1)$ \\
\hline
\end{tabular}

早期乳がん16例 (33.3)

( $2 \mathrm{~cm}$ 以下 $\mathrm{n} 0$ )

( ) :\%

径 $2 \mathrm{~cm}$ 以下でリンパ節転移はみとめられず早期乳 癌であった(表 3)。図 7 に早期乳癌例の超音波像を 示す。腫瘤径が $10 \mathrm{~mm}$ 以上あれば超音波画像上で 腫瘤と認識可能である。

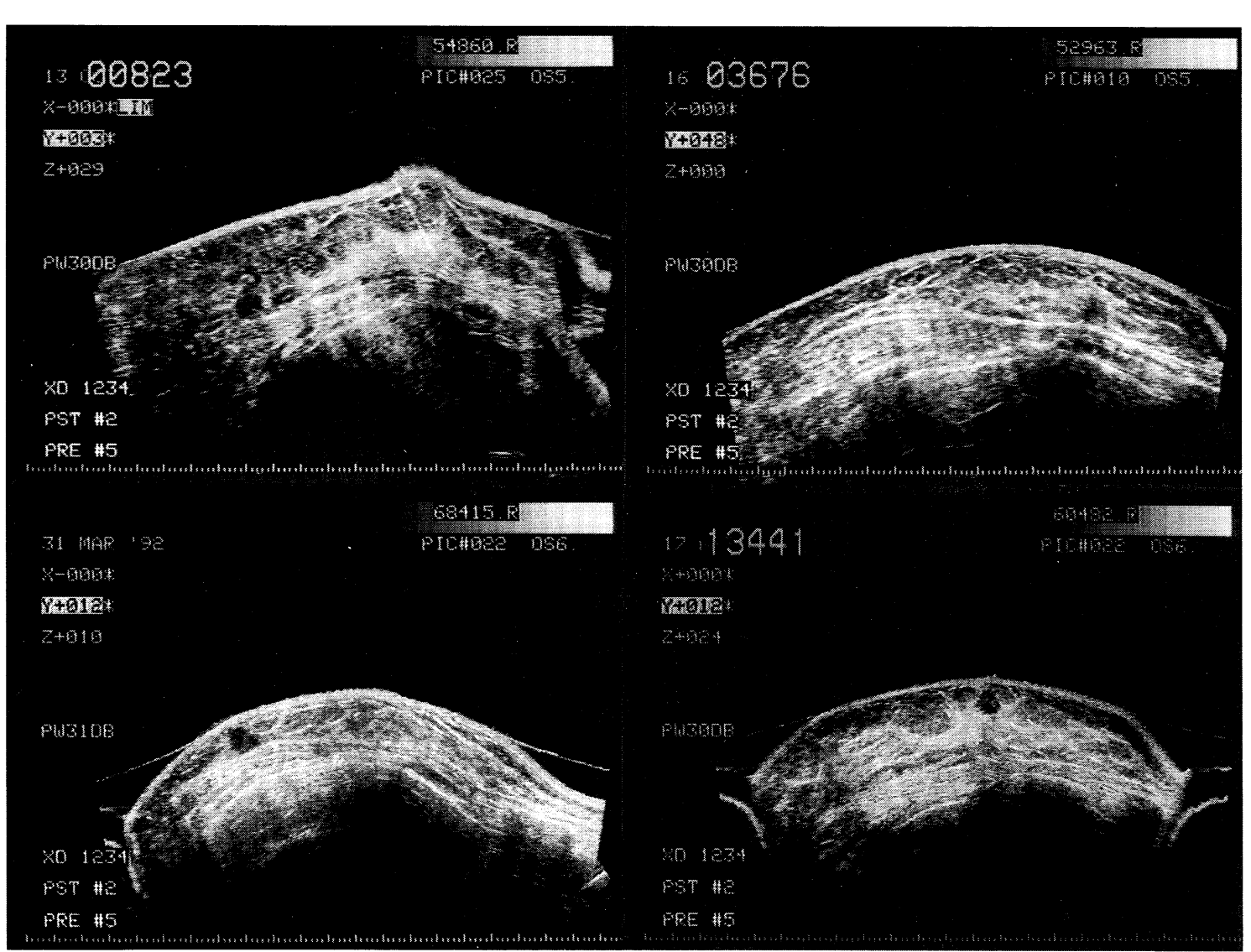

図 7. 早期乳癌例の超音波像 


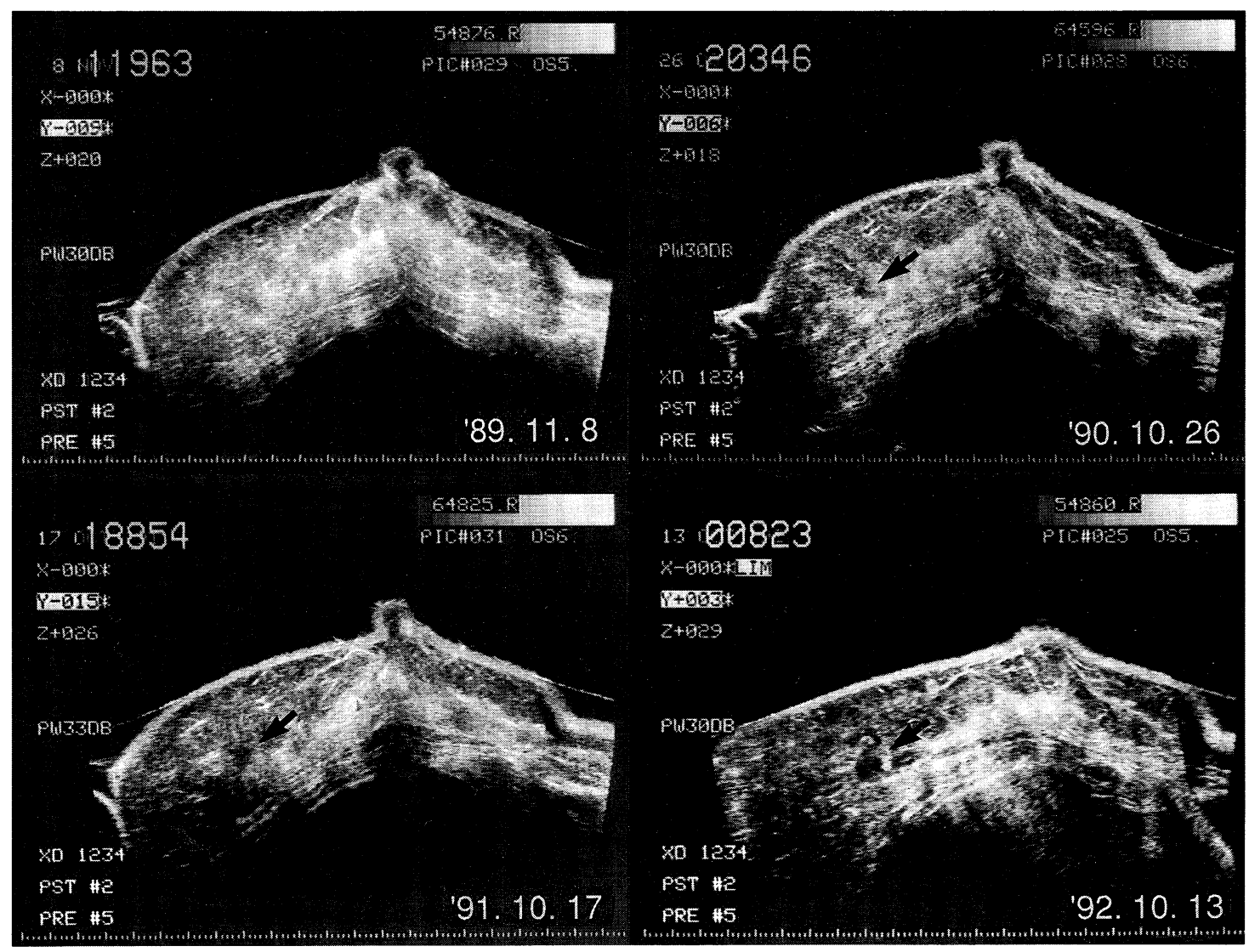

図 8. 繰返し受診者の 1 例

教育を老人保健事業に導入し, 市町村単位では乳 がん検診, 乳がん予防健康教育が広く行われるよ うになった。1989年度の老人保健事業実績では乳 がん予防健康教育 2,167 市町村 $(66.3 \%)$, 乳がん検 診は 2,757 市町村 $(84.3 \%)$ に実施されている。これ らのうち上のせ検診としてマンモグラフィは173市 町村 (5.3\%)，超音波は531市町村 $(16.2 \%)$ に行わ れている8)。これは, 最近のマンモグラフィにおい ては被曝線量の低減化がはかられており，住民検 診に用いることはまったく心配ないとの意見もあ るが，なお実施機関においては40歳未満の若年者 における撮影の是非とともに躊躇される点であり, また診断に耐えるマンモグラフィを撮像する技術, 読影のための医師の確保などの問題がある。現状 では以上のような実状から超音波による上のせが 多くの各市町村で実施されているものと推察され る。しかし，マンモグラフィは 1 枚の写真に乳房
全体の情報が集積して表現されるのに対して，超 音波では断層像として表現されており，乳房全体 を検診するためには多断層面の記録ならびに読影 が必要となり, 現在, 乳癌検診に適した専用の超 音波断層装置がないなどの問題がある。視触診法 と画像診断との関係において,植野ら ${ }^{9}$ は触診と超 音波診断は診断能において共通していることを指 摘しており，触診に超音波を上のせすることの意 義は少ないと述べている。大阪市においては種々 の検診方法を検討した後に，1988年11月より超音 波のみによる乳癌検診に踏み切った。超音波のみ による乳癌検診成績の報告は少ないが，大阪市の 乳がん検診では，要精検率が $10.9 \%$ とや高いも のの，乳がん発見率においては0.08\%であり，一 般の乳がん検診実績は，要精検率が 4 から $6 \%$ ， 乳癌発見率が0.07から0.11\%であるのに比べて遜 色なく, 早期乳癌割合も $33.3 \%$ あっあた。超音波 
検査は精密検查のみでなく一次集検としても有用 である。超音波のみによる乳癌検診の問題点とし ては, 要精検率が高く, 大きな腫瘤で見逃しがあっ たこと，検診に用いた超音波診断装置 $(\mathrm{MAT}-1)$ は各種のアーチファクトが多い10)ことなどがあげら れる。超音波検査のみによる乳癌検診を成功させ るためには保健婦による自己検診の指導，問診の 徹底, 超音波検査技師による良好な超音波画像の 撮像と, 習熟した超音波判定医による読影, 精度 管理のための症例検討会など，良いシステム作り が何よりも大切である。

\section{まとめ}

大阪市では1988年11月から視触診をせず，事前 に自己検診指導, 問診を徹底したのち超音波診断 装置(MAT- 1 , 5.5MHz のコンパウンドスキャナ) を積載した検診車により超音波断層像を撮影し， 乳がん検診超音波判定委員が読影判定する乳癌検 診を行い，以下の結果をえう。

1.1993年 3 月までに受診者 69,069 名に超音波検 診を施行し，要精検率は $10.9 \%$ ，精検受診率は $95.6 \%$, 発見乳癌は 57 例, 癌発見率は $0.08 \%$ であっ た。

2. 医療機関から精検結果の報告があった乳癌 48 例の年齢は36歳から 73 歳, 平均年齢は52.6歳, $\mathrm{T} 0$, Tis : 3 例, T $1: 18$ 例, T2:20例, T3 : 5例, T4 : 2 例, $\mathrm{n} 0: 28$ 例, $\mathrm{n} 1 \alpha: 8$ 例, $\mathrm{n} 1 \beta: 2$ 例, $\mathrm{n} 2: 2$ 例, 不明： 8 例, M0：47例, M1：1例であった。腫瘤 径は $5 \mathrm{~mm}$ から $72 \mathrm{~mm}$ まで平均 $28 \mathrm{~mm}$ であった。

3.乳癌48例中, 腫瘤自覚は31例 (64.6\%) で17例 (35.4\%) は繰返し受診者からの発見例であった。

4.最初の 2 年間に 6 例の見逃し例があったが, 最近 3 年間には見られていない。

\section{おわりに}

以上，超音波による大阪市乳がん検診のシステ ムならびに成績と問題点について述べた。

超音波検査のみによる乳癌検診を成功させるた めには保健婦による自己検診の指導, 問診の徹底, 超音波検査士による良好な超音波画像の撮像と習 熟した超音波判定医による読影，精度管理のため の症例検討会など良いシステム作りが何よりも大
切である。超音波検査は精密検査のみでなく一次 集検として有用である。

なお本研究は以下の大阪市乳がん超音波判定委 員, 大阪市環境保健局, 大阪市保健衛生検查所と の共同研究である。

\section{大阪市乳がん検診超音波判定委員会}

石田 武，大道道太，小川博康，佐々成紀，高橋 良和, 徳永 仰, 永井博敏, 中谷守一, 藤尾長久, 森本 健, 浅井 毅, 藤本泰久, 貴志彰宏, 金 義 哲, 宋 博, 三島紘一, 李 光春

大阪市環境保健局

朽木悦子

大阪市保健衛生検査所

武井節子，野口厚子，山田 智，蛇ヶ崎美和，中 村春巳，三笠雅昭，藤村太一郎

\section{【文 献】}

1）中谷守一, 横井 浩, 鄭 則之, 他：大阪市にお ける乳癌超音波集団検診——検診発見乳癌 8 例の 検討。日癌治，25：2204，1990

2) 月岡一馬, 横井 浩, 鄭 則之, 他: 大阪市にお ける乳がン検診：第 1 報。 日外会誌，92(臨時增 刊) : 249, 1991

3）中谷守一, 森本 健, 横井 浩, 他: 大阪市にお ける乳癌検診。日乳癌検診学会誌, $1 ： 85,1992$

4）藤村太一郎, 藤本泰久, 山田 智, 他: 乳癌超音 波集団検診で経験した症例の検討.日乳癌検診学 会誌, $1: 89,1992$

5）朽木悦子，寺方公子，継本 茂，他：大阪市にお ける乳がん検診(第 2 報). 日乳癌検診学会誌, 2 : 174, 1993

6）加藤保之, 横井 浩, 鄭 則之：超音波による大 阪市乳がん検診——とに発見乳癌例と問題点に ついて。超音波医，20：702-703，1993

7）和賀井敏夫, 堤 正夫：乳腺の集団検診. 日本超 音波医学会講演論文集, $42 ： 3-4,1983$

8）石塚正敏：老人保健事業における乳がん対策の現 状と課題. 日乳癌検診学会誌, $1: 1-4,1992$

9）植野映, 角田博子, 東野英利子：非触知乳癌の 発見——超音波診断. 日乳癌検診学会誌，1： $7-12,1993$

10）三笠雅昭, 加藤保之, 藤本泰久, 他 : オクトソン 方式超音波診断装置の撮影条件の検討. 日乳癌検 診学会誌， $2 ： 76,1993$ 